Dhaka Univ. J. Biol. Sci. 22(1): 47-54, 2013 (January)

\title{
ASSESSMENT OF DRIP AND FLOOD IRRIGATION ON BIOMASS PRODUCTION, NUTRIENT CONTENT AND WATER USE EFFICIENCY OF MAIZE (ZEA MAYS L.)
}

\author{
A.H.M.Z. Ali* , S.U. Ahmed, M.M. RaHMAn and M.K. RaHMAN \\ Department of Soil, Water \& Environment, University of Dhaka, Dhaka-1000, Bangladesh \\ Key words: Drip irrigation, Flood irrigation, Maize, Nutrient, Water use efficiency
}

\begin{abstract}
An experiment was conducted in wooden boxes to assess flood, surface and sub-surface drip irrigation on biomass production, nutrient content and water use efficiency of maize (Zea mays L.). Four levels of irrigation treatments were applied: (i) SD1 = Drip irrigation pipe was set up on the surface of the soil ; (ii) SSD2 = Drip irrigation pipe was buried up to $5 \mathrm{~cm}$ depth; (iii) SSD3 = Drip irrigation pipe was buried up to $7.5 \mathrm{~cm}$ depth and (iv) FI = Flood irrigation was practiced without any drip irrigation pipe. Leaf area, leaf area index and biomass production of maize were significantly $(\mathrm{p}<0.05)$ higher in SSD3 than SSD2 and FI treatments. Biomass production was 37.2, 41.1, 54.2 and $35.2 \mathrm{~g}$ in SD1, SSD2, SSD3 and FI treatments, respectively. Water use efficiency (WUE) was also significantly $(\mathrm{p}<0.05)$ higher in surface and sub-surface drip irrigation than flood irrigation. Values for WUEs were $0.248,0.298,0.430$ and $0.156 \mathrm{~kg} / \mathrm{m}^{3}$ in SD1, SSD2, SSD3 and FI treatments, respectively. As a result, all three drip irrigation treatments enhanced water use efficiencies than flood irrigation. Comparing the three drip irrigation treatments, significantly $(p<0.05)$ higher nitrogen was found both in leaf and stem (3.3 and 3.8\%) in sub-surface drip irrigation at $7.5 \mathrm{~cm}$ depth than flood irrigation (2.2 and 1.4\%). Although, potassium contents in leaf and stem were not significantly different between the treatments, but had a tendency to be higher in drip irrigation treatments. Above all, drip irrigation performed better with higher water use efficiency.
\end{abstract}

\section{Introduction}

Water is becoming scarcer to meet the needs of agricultural crops. In general, irrigation methods and practices which provide uniformity of application and movement of water through soils influence water use efficiency. A more economical use of water has become a doctrine in different parts of the world especially where (includes Bangladesh) water is scarce or expensive.

Benefits of drip irrigation have been documented by different researchers ${ }^{(1)}$. Drip irrigation method can be applied for optimal soil moisture for crop growth, water use by different crops, improved crop yield and quality, interaction of irrigation and application of fertilizer on crop growth, unsaturated soil water movement, irrigation water quality and the movement and distribution of salt in the root-zone, and irrigation system design

*Author for correspondence: <abuhena66@gmail.com>. 
and management( ${ }^{(2)}$. Flood irrigation practice may be replaced by drip irrigation ${ }^{(3)}$. Use of drip irrigation eliminated many variables found in other type of irrigation ${ }^{(4)}$. Water and nutrient acquisition by plants and the formation of a depleted zone in the immediate vicinity of the roots are the driving forces for solute movement towards the roots ${ }^{(5)}$. Irrigation also interacts with nutrient uptake and particular emphasis should be placed on water-nitrogen relations ${ }^{(6)}$.

Maize is essentiality a warm and humid season crop and in areas of mild climate it can be grown throughout the year. Maize cultivation covers only $0.25 \%$ of the net cropped area in our country ${ }^{(7)}$. Due to less cost of production compared to other crops (paddy, wheat, oil seeds etc.) and huge market demand from poultry and fisheries maize cultivation is increasing day by day in our country.

Therefore, the objective of this study was to assess flood, surface and sub-surface drip irrigation regarding biomass production, water use efficiency and nutrient content of maize.

\section{Materials and Methods}

The experiment was carried out in the net house of the Department of Soil, Water \& Environment, University of Dhaka, Bangladesh. Soil sample was collected from the bank of the river Turag (Near Baliarpur, Savar) at a depth of $0-15 \mathrm{~cm}$. It was ground and airdried and kept in plastic bags in the net house of the department to fill the wooden boxes. Soil had a pH of 6.5 and water holding capacity 33\%. Particle size distribution of the soil was $25 \%$ sand, $64 \%$ silt and $11 \%$ clay. The soil was silt loam in texture. Soil pH was measured electrometrically using Corning Glass Electrode $\mathrm{pH}$ meter at a soil : water $1: 2.5^{(8)}$. Hydrometer method was used for particle size distribution of soil(9).

Twelve wooden boxes were constructed in the premises of the Department of Soil, Water \& Environment. The size of each box was $122 \mathrm{~cm}$ long, $25 \mathrm{~cm}$ wide and $30 \mathrm{~cm}$ deep. Water proof paint was applied on outer side of the boxes. A white polythene sheet with the same size of the wooden box was placed in the box and filled it with the collected air-dry soil sample up to $30 \mathrm{~cm}$ depth. A basal dose of $\mathrm{N}: \mathrm{P}: \mathrm{K}$ fertilizers at the rate of $98: 28: 56 \mathrm{~kg}$ ha $^{(10)}$ as urea, triple super phosphate and muriate of potash was applied in each box and mixed thoroughly. A shade was constructed on the above of the boxes with the help of polythene sheet to save the boxes from climatological hazard.

There were: (a) Four levels of irrigation treatments (IR), i. e., (i) SD1 = Drip irrigation pipe was set up on the surface of the soil (0 $\mathrm{cm}$ depth); (ii) SSD2 = Drip irrigation pipe was buried up to $5 \mathrm{~cm}$ depth ; (iii) SSD3 = Drip irrigation pipe was buried up to $7.5 \mathrm{~cm}$ depth and (iv) FI = Flood irrigation was practiced without any drip irrigation pipe; (b) One cultivar (CV), Maize Pacific-555. One variety (CV) $X$ irrigation level (IR) was replicated $(\mathrm{R})$ three times. Therefore, $4(\mathrm{IR}) \times 1(\mathrm{CV}) \times 3(\mathrm{R})=12$ boxes were used in this 
experiment. Boxes were arranged in a completely randomized design in the net house of the premises mentioned above.

In front of each box a plastic container (10 litre) with an outlet (bib cock) of water was set up on top of the steel bar of the net house. A plastic pipe was then joined to the bib cock of the container and made it long up to the ground level of the wooden boxes. Drip irrigation pipes super typhoon 100 unit $40 \mathrm{~cm}$ distance between drippers (Netafim Israel) were joined with the plastic pipes using hose clamp. To know the moisture status of the soil, a tensiometer was set up in one box in each treatment at $20 \mathrm{~cm}$ depth and readings were recorded every day at 10.00 a.m. to maintain the field capacity $(-10 \mathrm{kPa})$ in each box. The matric potential of soil that corresponds best to water content at field capacity is $-10 \mathrm{kPa}^{(11)}$. Water was applied to each box when the tensiometer turns down below field capacity and leave for two hours to reach at equilibrium. A total amount of 225, 150, 138 and $126 / 10^{3} \mathrm{~m}^{3}$ water were applied in FI, SD1, SSD2 and SSD3 treatments, respectively. Water use efficiency (WUE) was determined as the ratio of total biomass (dry basis) for a particular treatment to the applied volume of water for that treatment ${ }^{(12)}$.

Seeds of maize ( Zea mays L.) supplied by Lal Teer Seed Ltd., Bangladesh were used. Local name of this variety was Maize Pacific-555. Before germination, seeds were soaked in water for 24 hours and allowed to germinate on soil for seven days in the dark at $27^{\circ} \mathrm{C}$. Germinated seeds were then transferred in small plastic container filled with soil and allowed to grow for one month. One month old seedlings @ 3 per box were transplanted at a distance of $40 \mathrm{~cm}$ (drip point) between plant to plant, running north to south.

Leaf area (length $\times$ width) was measured with the help of a ruler. Leaf area index (LAI) was calculated as a ratio between leaf area and ground area. Fresh weight of maize leaf and stem were taken just after collection of the whole plant with the help of a digital electric balance. Collected plant samples (both leaf and stem) were air dried and finally dried in an oven at $60-65^{\circ} \mathrm{C}$ for 48 hours and dry weight was taken.

For total nitrogen and potassium analysis, $0.1 \mathrm{~g}$ ground leaves and stems were digested with $5 \mathrm{ml}$ concentrated $\mathrm{H}_{2} \mathrm{SO}_{4}$ and $2 \mathrm{ml} \%$ (v/ $/$ ) solution of perchloric acid $(62 \%)$ in concentrated $\mathrm{H}_{2} \mathrm{SO}_{4}$. The digest was cooled and diluted to $100 \mathrm{ml}$ with deinonixed water ${ }^{(13)}$. The concentration of nitrogen in leaves and stems was determined following steam distillation in the presence of $40 \% \mathrm{NaOH}$ and titrated with $\mathrm{HCl}$. The concentration of potassium in leaves and stems was determined by feeding the extract into a flame photometer with a suitable filter.

Statistical analysis was made using SPSS version 15.0.

\section{Results and Discussion}

Variation in soil water potential during experimental period in different boxes is shown in Fig. 1. Lowest and highest values of soil water potential were 8.6 - 11.2, 9.0 11.2, 9.1 - 11.3 and 8.8 - 11.2 kPa in Box-1 (SD1), Box-4 (SSD2), Box-7 (SSD3) and Box-10 
(FI) treatments, respectively. Average values of soil water potential were 9.8, 9.7, 9.8 and $9.7 \mathrm{kPa}$ in Box-1, Box-4, Box-7 and Box-10, respectively.

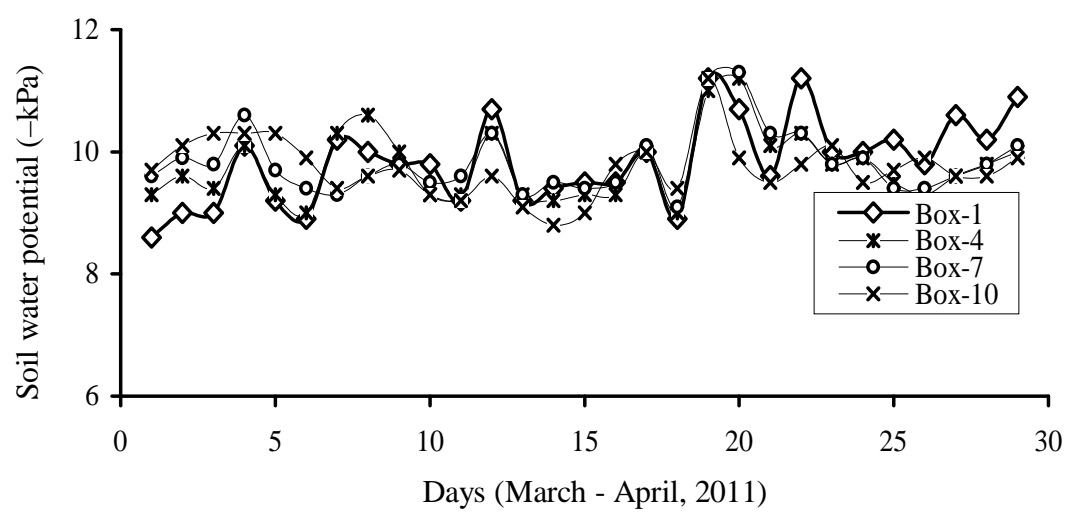

Fig.1. Variation in soil water potential during experimental period in different boxes.

Effects of flood, surface and sub-surface drip irrigation on fresh and dry weight of leaf of maize are shown in Fig. 2 a-b, respectively. Significant effects between flood and surface and sub-surface drip irrigation were observed for fresh weight of leaves of maize. In case of fresh and dry weight of stems of maize no significant differences were observed between flood and drip irrigation but, the tendency to be higher in drip irrigation treatments (data not shown). Fresh weight of leaf of maize was only significantly $(p<0.05)$ higher in SSD3 than SSD2 and FI treatments. Higher depth of drip irrigation also increased fresh weight of leaf of cabbage (Brassica oleracea L.) $)^{(14)}$.

Results of dry weight of leaf (Fig. 2b) were similar to fresh weight of leaf with a difference that dry weight of leaf for SSD3 treatment was significantly $(\mathrm{p}<0.05)$ higher than both SD1 and SSD2 treatments. Highest dry matter yield of cotton was also observed under well drip irrigated treatment ${ }^{(15-16)}$.

Effects of flood, surface and sub-surface drip irrigation on leaf area, leaf area index, biomass production and water use efficiency of maize are shown in Table 1. Significant effects between drip and flood irrigation were observed. Leaf area of maize was significantly $(\mathrm{p}<0.05)$ higher in surface (SD1) and subsurface drip (SSD3) irrigation than flood irrigation (F1). Leaf area index (LAI) was also significantly $(p<0.05)$ larger in SSD3 than FI treatment (Table 1). Maximum biomass above the ground was $54.2 \mathrm{~g}$ in SSD3 treatment. Surface (SD1) and sub-surface drip irrigation (SSD2 and SSD3) also had a significantly $(\mathrm{p}<0.05)$ greater WUEs. Among the four treatments, WUE was significantly $(\mathrm{p}<0.05)$ greater at higher depth of sub-surface drip irrigation (SSD3). Besides, plant growth is the integrated product of abiotic properties of the environment and numerous biologically mediated chemical reactions that occur in soil and plant. Water use by plants 
is controlled mainly by the abiotic properties of the environment in which they grow ${ }^{(17)}$. Water use efficiency ( WUE) values for drip irrigation were always greater than those for flood irrigation for sugerbeets(2). WUE increased with increasing water table depth in bell pepper (Capsicum annum L.)(6) and authors concluded that bell pepper yield was affected by water limitation and could benefit from abundant irrigation especially if applied as drip irrigation.
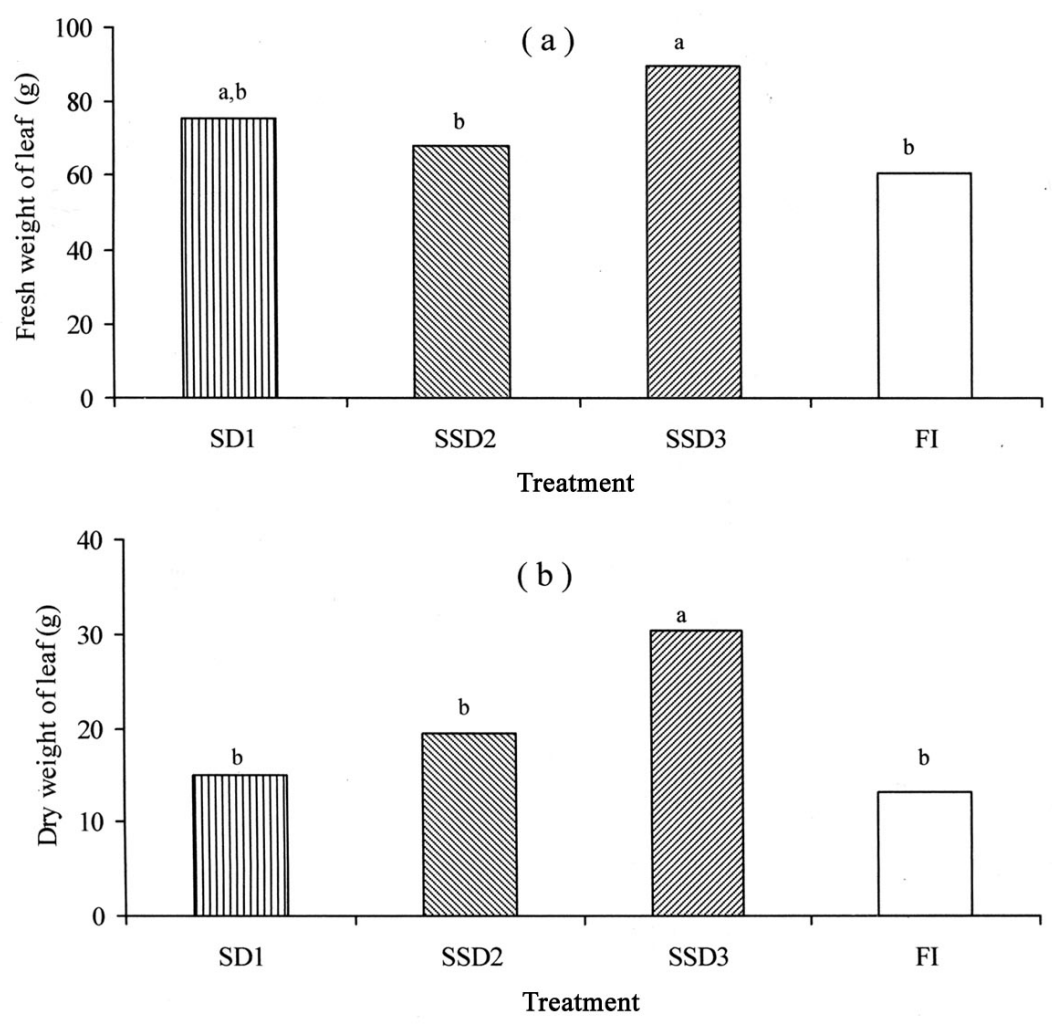

Fig. 2. Effects of flood, surface and sub-surface drip irrigation on (a) fresh weight and (b) dry weight of leaf of maize. Values that do not differ significantly $(p<0.05)$ share the same letter.

Mean values of total K content in leaf were 18.7, 19.0, 19.4 and $18.3 \mathrm{ppm}$ and in stem 19.9, 22.2, 22.9 and $20.1 \mathrm{ppm}$ for SD1, SSD2, SSD3 and FI treatments, respectively. No significant ( $\mathrm{p}>0.05$ ) differences were found between flood, surface and sub-surface drip irrigation, but had a tendency to be higher in drip irrigation treatments. Nutrient transport from the soil solution to the root surface takes place by two simultaneous processes: convection and diffusion ${ }^{(18)}$. Diffusion is the governing mechanism for the less mobile nutrient potassium(19). As a result, drip water application might have no significant effect on potassium content of maize. 
Effects of flood, surface and sub-surface drip irrigation on total nitrogen content in (a) leaf of maize and (b) stem of maize are shown in Figs 3a,b, respectively. Significant effects between flood and drip irrigation and surface and sub-surface drip irrigation

Table 1. Effects of flood, surface and sub-surface drip irrigation on leaf area, leaf area index, biomass production (total dry weight of leaf and stem) and water use efficiency of maize.

\begin{tabular}{lcccc}
\hline Treatments & $\begin{array}{c}\text { Leaf area } \\
\left(\mathrm{m}^{2}\right)\end{array}$ & $\begin{array}{c}\text { Leaf area index } \\
(\mathrm{LAI})\end{array}$ & $\begin{array}{c}\text { Biomass (Dry weight } \\
\text { of leaf and stem) }(\mathrm{g})\end{array}$ & $\begin{array}{c}\text { Water use efficiency } \\
\left(\mathrm{kg} / \mathrm{m}^{3}\right)\end{array}$ \\
\hline SD1 & $0.622^{\mathrm{a}}$ & $5.0^{\mathrm{a}, \mathrm{b}}$ & $37.2^{\mathrm{b}}$ & $0.248^{\mathrm{b}}$ \\
SSD2 & $0.553^{\mathrm{a}, \mathrm{b}}$ & $4.5^{\mathrm{a}, \mathrm{b}}$ & $41.1^{\mathrm{b}}$ & $0.298^{\mathrm{b}}$ \\
SSD3 & $0.658^{\mathrm{a}}$ & $5.3^{\mathrm{a}}$ & $54.2^{\mathrm{b}}$ & $0.430^{\mathrm{a}}$ \\
FI & $0.458^{\mathrm{b}}$ & $3.7^{\mathrm{b}}$ & $35.2^{\mathrm{a}}$ & $0.156^{\mathrm{c}}$ \\
\hline
\end{tabular}

$a, b, c$ Data bearing different superscripts within the same column differ significantly $(p<0.05)$.
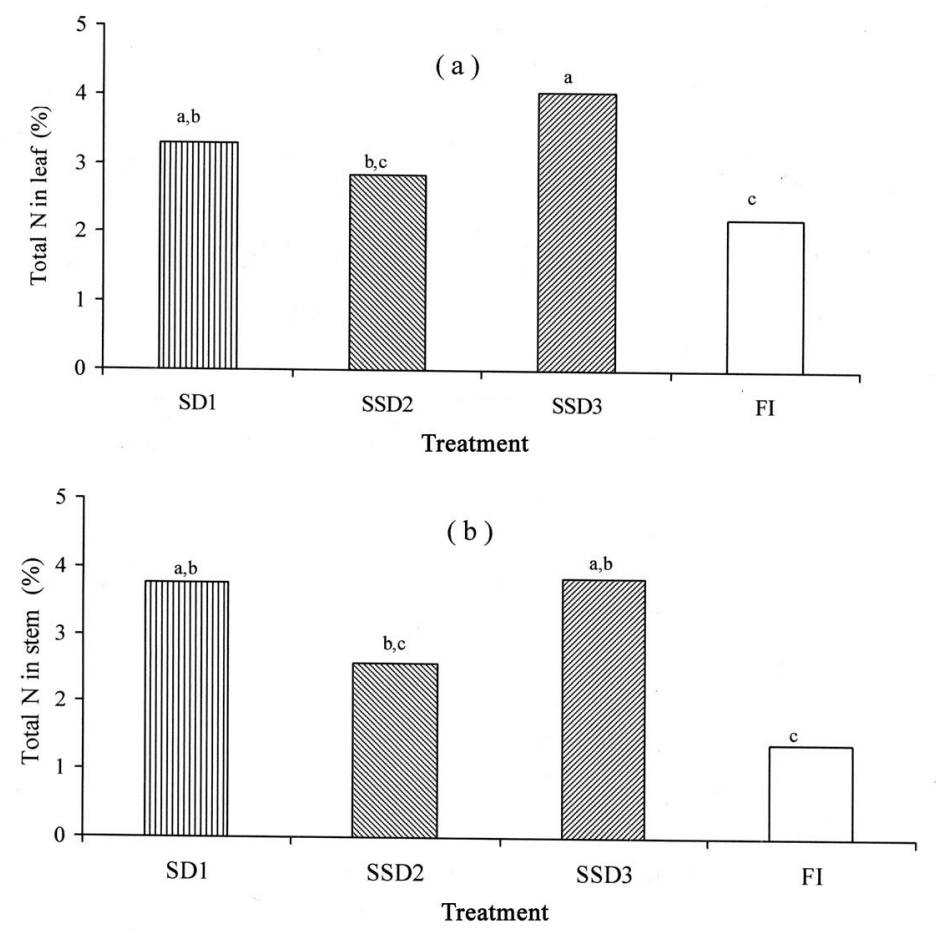

Fig. 3. Effects of flood, surface and sub-surface drip irrigation on the total nitrogen content of (a) leaf of maize and (b) stem of maize. Values that do not differ significantly $(\mathrm{p}<0.05)$ share the same letter.

were observed. In this case, total $\mathrm{N}$ content of leaf and stem of maize were significantly $(\mathrm{p}<0.05)$ higher in SSD3 and SD1 than FI treatment. Total-N content of leaf was also significantly $(p<0.05)$ higher in SSD3 than SSD2. No differences were observed between 
surface and sub-surface drip irrigation for nitrogen content of stem. Nitrogen concentration in the leaf of tomato plants were also higher with sub-surface drip irrigation ${ }^{(20)}$. Comparing drip and flood irrigation, Geleta et al. ${ }^{(21)}$ concluded that drip irrigation resulted in lower $\mathrm{NO}_{3}{ }^{-} \mathrm{N}$ loss. Under certain soil and environmental conditions, the corn plant may store an excessive amount of nitrogen compounds. The highest concentrations of excessive nitrogen usually are in the lower portion of the stalk(22).

All three drip irrigation treatments enhanced water use efficiencies. Comparing drip and flood irrigation methods, higher biomass, nitrogen, potassium and greater WUE were found in sub-surface drip irrigation at $7.5 \mathrm{~cm}$ depth. Generally, in flood irrigation method, losses of water occurred mainly in the conveyance, application, percolation, evaporation and runoff which are reduced in drip irrigation method. Hence, drip irrigation performed better with higher water use efficiency.

\section{Acknowledgements}

Authors are grateful to the Ministry of Science and Information \& Communication Technology, Govt. of the People's Republic of Bangladesh for providing the fund for this research work, Mr. G. M. Mohsin, Lal Teer Seed Limited, Gazipur, Dhaka for supplying Maize Pacific-555 seeds, Dr. K. Ozawa and Dr. Ken Nakamura of Okinawa Subtropical Station of Japan International Research Centre for Agricultural Sciences (JIRCAS), Japan for generous help by providing tensiometer and drip irrigation pipes for this experiment.

\section{References}

1. Sharmasarkar FC, S Sharmasarkar, SD Miller, GF Vance and R Zhang 2001. Assessment of drip and flood irrigation on water and fertilizer use efficiencies for sugarbeets. Agric. Water Management 46: 241- 251.

2. Michael AM 1996. Irrigation - Theory and Practice. pp. 801. Vikas Publishing House Pvt. Ltd. New Delhi, India.

3. Bihery MA and TE Lachmar 1994. Groundwater quality degradation as a result of over pumping in the delta Wadi El-Arish area, Sinai Peninsula, Egypt. Environ. Geol. 24: 293305.

4. Comis D. 2011. Economics of limited irrigation. Agricultural Research. US Department of Agriculture, USA.

5. Silber A, G Xu, I Levkovitch, S Sorianol, A Bilu and R Wallach 2003. High fertigation frequency: the effects on uptake of nutrients, water and plant growth. Plant and Soil. 253: 467-477.

6. Dalla Costa L and G Gianquinto 2002. Water stress and water table depth influence yield, water use efficiency, and nitrogen recovery in bell pepper: Lysimeter studies. Aust. J. Aric. Res. 53: 201-210.

7. Bangladesh Bureau of Statistics (BBS). 2004. Statistical Yearbook of Bangladesh. Bureau of Statistics, Ministry of Planning, Dhaka, Bangladesh. 
8. Jackson ML 1967. Soil Chemical Analysis. Printice Hall of India Pvt. Ltd., New Delhi.

9. Bouyoucos GJ 1962. Hydrometer method improved for making particle analysis of soil. Agron. J. 54: 464-465.

10. Bangladesh Agricultural Research Council (BARC) 2005. Fertilizer Recommendation Guide. BARC Soils Publication No. 45. Peoples Press \& Publications, Purana Paltan, Dhaka.

11. Marshall TJ and JW Holmes 1992. Soil Physics. pp. 256. Athenaeum Press Ltd., UK.

12. Howell TA, A Yazar, AD Schneider, DA Dusek and KS Copeland 1995. Yield and water use efficiency of corn in response to LEPA irrigation. Transactions of the ASAE. American Society of Agricultural Engineers 38(6): 1737-1747.

13. Cresser M and JW Parsons 1979. Sulphuric-percholric acid digestion of plant material for the determination of nitrogen, phosphorus, potassium, calcium and magnesium. Anal. Chim. Acta. 109: 431-436.

14. Ali AHMZ, MM Rahman, B Faiz and MK Rahman 2006. Effects of depth of subsurface drip irrigation on the growth of Chinese cabbage (Brassica oleracea L.). J. Asiat. Soc. Bangladesh. 32 (1): 165-170.

15. Moreshed S, M Fuchs and Y Cohen 1996. Water transport characteristics of cotton as affected by drip irrigation. Agron. J. 88: 717-722.

16. Ertek A and R Kanber 2001. Effects of different irrigation programs on the growth of cotton under drip irrigation. Turkish J. Agric. Forest. 25: 415-425.

17. Power JF 1983. Soil management for efficient water use: Soil fertility. In: Limitations to efficient water use in crop production ( Taylor HM Ed.), pp. 461-470. ASA-CSSA-SSSA, Madison, WI 53711, USA.

18. Jungk AO 1996. Dynamics of nutrient movement at soil-root interface. In: Plant Roots The Hidden Half (Waisel Y, A Eshel and U Kafkafi Eds), 2 ${ }^{\text {nd }}$ edition, pp. 529-556. Marcel Dekker, Inc. New York.

19. Mmolawa K and D Or 2000. Root zone solute dynamics under drip irrigation: A review. Plant and soil 222: 163-190.

20. Badr MA and AA Abou El-Yazied 2007. Effect of fertigation frequency from subsurface drip irrigation on tomato yield grown on sandy soil. Aust. J. Basic \& Appl. Sci. 1(3): 279-285.

21. Geleta S, GJ Sabbagh, JF Stone, RL Elliot, HP Map, DJ Bernardo and KB Watkins 1994. Importance of soil and cropping systems in the development of regional water quality policies. J. Environ. Qual. 23: 36- 42.

22. Wheaton HN, F Martz, F Mainershagen and H Swell 1993. Corn Silage. Department of Agronomy and Department of Animal Sciences, University of Missouri, USA. 